Sebastian Urbaniak

\title{
HISTORIOGRAFOWIE VI I VII WIEKU O DZIEJACH SŁOWIAN: PRZEGLĄD KONTROWERSJI W PISMACH MARIANA PLEZI, GERARDA LABUDY, HENRYKA ŁOWMIAŃSKIEGO I LECHA TYSZKIEWICZA
}

Problem etNogenezy bywał niejednokrotnie przedmiotem uwagi historyków. Do kluczowych zadań historyków polskich w tym zakresie należała próba krytycznego skompilowania źródeł pisanych do historii Słowian. Podstawowym zaś problemem jest brak własnych świadectw pisanych u Słowian, toteż kompilowane źródła odnośnie do najwcześniejszych dziejów Słowian są napisane przez obcych względem Słowian pisarzy. Do najważniejszych prób kompilacji należy zaliczyć dzieła Mariana Plezi, Gerarda Labudy oraz Jerzego Kolendy, a także wciąż trwające prace nad I tomem testimoniów do dziejów Słowian (do tej pory wydanych zostało pięć kolejnych tomów). Zauważyć również wypada wielce wpływową krytykę źródeł pisanych dokonaną przez Henryka Łowmiańskiego w jego monumentalnym dziele o początkach Polski oraz zakrojone na mniejszą skalę, ale równie inspirujące poznawczo, refleksje Lecha Tyszkiewicza. Osobnym wreszcie problemem jest krytyczna recepcja dwóch podstawowych dzieł dla rekonstrukcji procesu etnogenetycznego Słowian, a więc Germanii Tacyta oraz Geticów Kasjodora/Jordanesa. Dzieło Tacyta stanowi szczególny przedmiot badań zapoczątkowanych przez Kolendę oraz badaczy wokół niego skupionych, natomiast Getica Kasjodora/Jordanesa zostały przetłumaczone oraz 
zaopatrzone w aparat krytyczny przez Edwarda Zwolskiego. Osobnej uwadze ujść nie może stanowisko prezentowane ostatnio przez część archeologów, którzy negują możliwości wykorzystania źródeł pisanych dla rekonstruowania procesu etnogenezy Słowian (np. Henryk Mamzer, Janusz Ostoja-Zagórski). Niniejszy tekst stanowi próbę przeglądu interpretacji tekstów z VI i VII wieku dotyczących Słowian przez polskich historyków: Łowmiańskiego, Labudę, Plezię i Tyszkiewicza. Jako taki nie rości sobie pretensji do bycia wyczerpującym studium historiograficznym, poprzestając raczej na zasygnalizowaniu najbardziej kluczowych problemów, będących przedmiotem przeszłych dyskusji i polemik. Celem autora jest uchwycenie ogólnego klucza, według którego słowiańskie dzieje referowane przez historyków z VI i VII wieku reinterpretowane były przez polskich historyków.

Specyfika źródła historiograficznego daje asumpt do zastanowienia się nad rolą źródła dla badań etnogenetycznych, a także dla (re)konstruowania przeszłości w ogóle. Zauważyć bowiem należy, że mamy do czynienia $\mathrm{z}$ pewnym nieporozumieniem $\mathrm{w}$ kwestii interpretowania stanowiska i jego oceny pod kątem źródła. Z jednej strony mamy dzisiaj badaczy, którzy swoje rekonstrukcje opierają przede wszystkim na źródłach pisanych, uznając je za najważniejsze źródło dla poznawania przeszłości. ${ }^{1} \mathrm{Z}$ drugiej strony - wśród historyków i archeologów zaznacza się tendencja do ujmowania źródeł archeologicznych jako podatnych na subiektywizację, równie podatnych - co warte podkreślenia! - co źródła pisane. ${ }^{2} \mathrm{~W}$ pierwszym przypadku

\footnotetext{
${ }^{1}$ M. SAlAmon, „Ku nowej tożsamości etnicznej. Plemiona germańskie na Wschodzie (III-IV w. n.e.)", [w:] M. SAlAmon, J. STRZElczyK (red.), Wędrówka i etnogeneza w starożytności i średniowieczu, Kraków 2010, s. 160. Por. uwagi K. Godłowskiego: „W moich rozważaniach będę się zasadniczo opierał na dwóch kategoriach źródeł - archeologicznych i pisanych, pomijając z pewnymi wyjątkami argumenty wywodzące się z arsenału innych nauk" (K. God£owski, $Z$ badań nad zagadnieniem rozprzestrzenienia Stowian $w$ V-VII w. n.e., Kraków 1979, s. 2) oraz o „niebezpiecznej z metodycznego punktu widzenia praktyce korygowania jednoznacznej wymowy źródeł pisanych [podkreślenie SU]” (K. GoDŁOwsKI, „W sprawie znaczenia ceramiki dla badań nad pierwotnymi siedzibami Słowian”, [w:] idem, Pierwotne siedziby Stowian, Kraków 2000, s. 97).

${ }^{2}$ E. DomańskA, „Tekstualizacja archeologii (od Barthesa do Hoddera)”, [w:] J. OstojAZAGóRSKI (red.), fakiej archeologii potrzebuje współczesna humanistyka?, Poznań 1997; por. również: D. MinTA-TworzowsKA, „Źródło/Ślad/Artefakt/Rzecz/Przedmiot”, [w:] S. TABAczyński, A. Marciniak, D. Cyngot, A. Zalewska (red.), Przeszłość spoteczna. Próba koncep-
} 
mamy więc do czynienia z obiektywizacją źródeł pisanych, z drugiej - tekstualizacją źródła archeologicznego. Optymizm pierwszej postawy zderza się ze sceptycyzmem drugiej.

To historiografowie wypracowali jako pierwsi modele etnogenezy, do których zaczęto się odnosić w interpretacjach archeologicznych oraz językoznawczych. Podstawowe założenia, które kształtują w ogóle myślenie archeologów, są założeniami wyniesionymi z nauki historii. ${ }^{3}$ Słusznie podnoszono wielokrotnie, że założenia owe to główne idee cywilizacji nowożytnoeuropejskiej porządkujące rzeczywistość według zapotrzebowania w procesie czasoprzestrzennej kolonizacji. ${ }^{4}$ Jednak podczas gdy źródła pisane (historyczne) zawsze są epifenomenem kultury, w której powstały - poza tą jedną jedyną cechą, jaką jest ich niewątpliwa materialność jako druk, książka czy jakakolwiek inna forma - źródła archeologiczne (jako rzeczy) są zanurzone w rzeczywistości. ${ }^{5}$

Funkcjonujące do dziś modele etnogenezy, jak wskazują Kolendo oraz Jerzy Strzelczyk, zostały wypracowane jeszcze przez historiografów antycznych, rozbudowane zaś przez historyków średniowiecznych. Dominujący model allochtoniczny przybierał postać narracji bądź o inwazji i podboju (np. Sasi), bądź o asymilacji i zmieszaniu tubylców z przybyszami (np. Beltiberowie, Bastarnowie). Allochtoniczny model pochodzenia ludów został zaadaptowany również przez chrześcijańskich historyków średniowiecza. Wyrażany przez nich pogląd zwany allochtonizmem biblijnym opierał się na relacji Księgi Wyjścia, wywodząc wszystkie współczesne i historyczne ludy od potomków Noego. ${ }^{6}$ Model ten zyskał popularność głównie dzięki pismom

tualizacji, Poznań 2012, s. 140-146. Jeszcze innym przypadkiem jest stanowisko, które neguje w ogóle istnienie jakichkolwiek pewnych informacji dotyczących najdawniejszych dziejów Słowian, np. L. Niederle (zob. cytat rozpoczynający: G. LABUDA, „Okres wspólnoty słowiańskiej w świetle źródeł i tradycji historycznej”, [w:] idem, Fragmenty dziejów Stowiańszczyzny Zachodniej, t. 1, Poznań 1960, s. 181-226).

${ }^{3}$ J. Topolski, Metodologia historii, Warszawa 1968, s. 29-34.

${ }^{4}$ H. Mamzer, Archeologia i dyskurs. Rozważania metaarcheologiczne, Poznań 2004, s. 24.

${ }^{5}$ E. DomańsKa, „Problem rzeczy we współczesnej archeologii”, [w:] J. KowalewsKi, W. PIASEK, M. ŚLIWA (red.), Rzeczy i ludzie. Humanistyka wobec materialności, Olsztyn 2008, s. 27-60.

${ }^{6}$ J. STrzzlczyK, „Etnogeneza Słowian w świetle źródeł pisanych”, [w:] P. KACZANowsKi, M. PArczewski (red.), Archeologia o początkach Stowian. Materiaty z konferencji, Kraków, 
Izydora z Sewilli (VII w.), jednak bez wątpienia okolicznością ułatwiającą jego rozpowszechnienie były prostota i schematyzm, jaki umożliwiał przy przedstawieniu genealogii ludów. ${ }^{7}$ Mappa mundi autorstwa Izydora stanowi próbę odczytania historii poprzez wizję chrześcijańskiej eschatologii. Dopiero wraz z powrotem idei Rzymu jako spełnionego w przeszłości zwornika kontynentów, model genezy, którego summę stanowiło dzieło Izydora, odszedł w cien. ${ }^{8}$

Nieco rzadziej spotykany model etnogenezy u pisarzy wczesnośredniowiecznych wiąże genealogię biblijną z dziejami antycznego świata Greków i Rzymian, jak ma to miejsce w przypadku Kroniki polskiej Wincentego zwanego Kadłubkiem, według której Lechici walczyli z Aleksandrem Wielkim oraz Juliuszem Cezarem. ${ }^{9} \mathrm{~W}$ obu przypadkach mamy też do czynienia z wpleceniem własnej nierozpoznanej do końca historii w tryby historii lepiej opisanych oraz lepiej udokumentowanych. ${ }^{10}$

Nawiązywała do nich m.in. kronika ruska znana pod nazwą Latopisu Nestora, której autor uznaje Słowian za potomków Jafeta, którzy osiedlili się na obszarach naddunajskich, skąd dalej mieli rozejść się nad Wisłę po Dniepr, przy czym po raz pierwszy odwrócony zostaje u Nestora kierunek wędrówki: z południa (Panonia) na północ. ${ }^{11}$ Koncepcję tę przejął i rozbudował kronikarz polski Jan Długosz, który wywodził Słowian od Sarmatów, zmieniając również trasę tej wielkiej migracji: nie przez Bałkany, ale przez Kaukaz. Stąd zaś mieli iść $\mathrm{w}$ dwóch grupach na zachód i na południe. ${ }^{12} \mathrm{Za}$ dalekie echo

19-21 listopada 2001, Kraków 2005, s. 15-30, na s. 21-22; J. KolENDO, „Mity etnogenetyczne w starożytności a kształtowanie się pojęć autochtonizmu i allochtonizmu”, [w:] SALAMON, STRZELCZYK (red.), Wędrówka i etnogeneza (cyt. w przyp. 1), s. 9-27.

${ }^{7}$ A. JANACZEK, „Świadomość wspólnoty słowiańskiej w pełnym i późnym średniowieczu”, [w:] S. R. Kalembek, A. Cetnarowicz (red.), Stowianie - idea i rzeczywistość. Zbiór studiów, Poznań 2013, s. 74.

${ }^{8}$ S. Rosik, Conversio gentis Pomeranorum: studium świadectwa o wydarzeniu (XII w.), Wrocław 2010, s. 17-18.

9 J. Wyrozumski, „Mity o pochodzeniu”, [w:] M. Bobrownicka, L. SuchaneK, F. ZiejKA (red.), Wspótcześni Stowianie wobec własnych tradycji i mitów. Sympozjum w Castel Gandolfo, 19-20 sierpnia 1996 r., Kraków 1997, s. 19.

${ }^{10}$ Ibidem, s. 16.

${ }^{11}$ STRZelczYK, „Etnogeneza Słowian” (cyt. w przyp. 6), s. 25.

${ }^{12}$ Ibidem, s 26-27 
tych poglądów Zbigniew Sułkowski uznał teorie pochodzenia Indoeuropejczyków z Azji. ${ }^{13}$

Model autochtoniczny wydawał się najmniej ulubionym wyjaśnieniem genezy ludów w oczach pisarzy greckich, zyskując na wadze dopiero w czasach dalekosiężnej ekspansji Imperium Rzymskiego, czego dowodem wielce wpływowy opis autochtonizmu Germanów zaprezentowany przez Tacyta. ${ }^{14}$ W polskiej literaturze problemowi Tacytowej Germanii i rekonstrukcji na jej podstawie mapy etnicznej środkowoeuropejskich społeczności barbarzyńskich poświęcił najwięcej uwagi Kolendo, ${ }^{15}$ udowadniając, że informacje w niej zawarte świadczą na korzyść teorii allochtonicznej.

$\mathrm{Z}$ metodologicznego punktu widzenia należy zdecydowanie odróżnić od siebie świadectwa pisarzy współczesnych wydarzeniom, które można określić jako wczesne dzieje Słowian, od świadectw, które zostały napisane z późniejszej perspektywy, a także od tej jednej, szczególnej relacji opisującej wydarzenia z I w. n.e., jaką jest Germania Tacyta. Na problem ten należy spojrzeć w perspektywie definicji i kryteriów autentyczności, zaprezentowanych przez Jerzego Topolskiego, ${ }^{16}$ interpretowanych przez Wojciecha Wrzoska jako przykłady stronniczości historycznej (kulturowej). ${ }^{17}$ Każda bowiem wypowiedź historyczna powstaje w swoistym momencie i w specyficznej kulturze, które razem określają instrumentarium metaforyczne, kategoryzujące rzeczywistość badacza. Wyjście poza te kategorie jest - zdaniem Wrzoska - niemożliwe, bowiem granice naszego języka wyznaczają granice naszego świata (poznania).

Nadto jeszcze trzeba zwrócić uwagę na wewnętrzne zróżnicowanie celów przyświecających historiografii rzymskiej i bizantyńskiej, tzn. na stronniczość w obrębie pewnej jednej, wyszczególnionej epoki, wśród któ-

\footnotetext{
${ }^{13}$ Z. SuŁкоwSKI, „Allochtoniści i autochtoniści” [w:] Spór o Stowian, Warszawa 1986, s. 6.

${ }^{14}$ Szczególnym przypadkiem (re)interpretacji tekstu Tacyta stanowi jego pozycja w nauce niemieckiej schyłku XVIII i początku XIX w. Por. J. KMIECIŃskI, Rekonstrukcja minionych kultur, Lublin 1997, s. 47 i n.

${ }^{15}$ M.in. J. KolEndo, „Mapa etniczna środkowoeuropejskiego Barbaricum. Swebia i Lugiowie w Germanii Tacyta", [w:] Kaczanowski, Parczewski (red.), Archeologia o poczattkach Stowian (cyt. w przyp. 6), s. 103-118.

${ }^{16}$ Topolski, Metodologia (cyt. w przyp. 3), s. 296-298 i n.

${ }^{17}$ W. WrzoseK, O myśleniu historycznym, Bydgoszcz 2009, s. 29-30.
} 
rych wymienia się kierunki retoryzujący i perypatetyczny, które żądają od autorów nie tylko poznawania prawdy, ale również „zainteresowania pięknym stylem” oraz „zabawiania czytelnika” ${ }^{18}$ Zdecydowanie należy również podkreślić, że relacje pisarzy bizantyńskich koncentrowały się na praktycznych zagadnieniach, mających np. znaczenie w walce (Strategikon PseudoMaurycego), zawsze spowinowaconych $\mathrm{z}$ aktualną linią polityczną cesarstwa. Dlatego Słowianie występują w źródłach o tyle, o ile mają jakiekolwiek znaczenie dla polityki cesarstwa. Gdy tracą na znaczeniu, zaznacza się brak Słowian w źródłach. Jak zauważa nadto Przemysław Urbańczyk, historiografowie antyczni używając etnonimów nie pisali historii „narodów” takich, jak je rozumiemy współcześnie, lecz dzieje elit, owych zworników tradycji, z którymi identyfikowano migrujące z nimi otoczenie. ${ }^{19}$

Pomimo tych zastrzeżeń, Lech Tyszkiewicz skłonny jest uznać, że informacje podane w bizantyńskich źródłach z VI i VII, a także pierwszych dekad VIII w. są pewne i przez nikogo nie kwestionowane. Dotyczy to zarówno nazw ludów - Sklawinowie i Antowie - jak również położenia ich siedzib na północ od Istru, czyli dolnego Dunaju. Gorzej przedstawia się sytuacja z osadnictwem Słowian w kierunku zachodnim, północnym i wschodnim. W tym wypadku dysponujemy tylko nieprecyzyjnymi wiadomościami Prokopiusza i Teofylakta. ${ }^{20}$

Podobny optymizm poznawczy prezentuje Labuda, zaznaczając, że dociekania etnogenetyczne nie powinny się ograniczać do tej lub innej koncepcji o praojczyźnie Słowian, ale że różne koncepcje mogą mieć zastosowanie biorąc pod uwagę szczególny moment historyczny owej etnogenezy „pod warunkiem, że dokładniej sprecyzujemy ramy chronologiczne, w których

\footnotetext{
${ }^{18}$ J. Kuranc, „Sposób przedstawiania dziejów przez historyków wczesno-bizantyńskich (V i VI w.)", Roczniki humanistyczne 6/2 (1956), s. 75; por. T. Sinko, Literatura grecka, t. 3, cz. 2, Wrocław - Warszawa - Kraków - Gdańsk - Łódź 1954, s. 338. W końcu, L. Tyszkiewicz podnosi jeszcze problem fundamentalnej różnicy źródeł antycznych i (wczesno)średniowiecznych, który uniemożliwia ich żonglowaniem przy powoływaniu argumentów na poparcie własnych tez, np. fakt, że w czasach antycznych autorami dzieł historiograficznych byli przede wszystkim wysoko postawieni urzędnicy świeccy, natomiast $\mathrm{w}$ średniowieczu dostojnicy kościelni; por też uwagi o historiografii bizantyńskiej w: L. TyszKIEwICz, Stowianie w historiografii antycznej do połowy VI wieku, Wrocław 1994, s. 8.

${ }^{19}$ P. UrbańczyK, Wtadza i polityka we wczesnym średniowieczu, Wrocław 2000, s. 126.

${ }^{20}$ Tyszkiewicz, Stowianie $w$ historiografii (cyt. w przyp. 18), s. 90.
} 
poszczególne stadia bytowania Słowian na tych przestrzeniach miały miejsce. Kto wypowiada sąd, że prasiedzibą Słowian aż do chwili ostatecznego ich rozejścia się w wieku VI n.e. był stale jeden i ten sam region - niewątpliwie błądzi”. ${ }^{21}$

Zdecydowanie gorzej przedstawia się również sytuacja Słowian do V/VI w., na czym zaważył, wzmiankowany przez Łowmiańskiego, Tadeusza LehraSpławińskiego oraz Tyszkiewicza fakt oddzielenia siedzib najpierw Protosłowian, a później Słowian od centrum świata śródziemnomorskiego

przez nomadów znad Pontu, jak Scytów, Sarmatów, przez jakiś czas przez obydwa odłamy Gotów, potem przez Hunów i w mniejszym stopniu Awarów, przy jednoczesnym niedopuszczaniu do nich na zachodzie wpływów rzymskich przez różne plemiona starożytnej Germanii. ${ }^{22}$

Należy przypuszczać, że jakiekolwiek dociekanie obecności lub poszukiwanie siedzib Słowian do początków naszej ery będzie stanowiło zawsze przedmiot domysłów i chwiejnych hipotez. Identyfikowanie któregoś z niescytyjskich ludów wzmiankowanych przez Herodota ze Słowianami nie ma żadnego oparcia w późniejszych źródłach. Wyjątkową popularność zyskała teza identyfikująca przodków Słowian z Herodotowymi Neurami, zwanymi również Budynami. W tym tzw. okresie neuryjskim siedziby przodków późniejszych Słowian miały rozciągać się na olbrzymim obszarze, uwzględniając obszar Polski z Wielkopolską (Plezia, Lehr-Spławiński). Próba konfrontacji tego poglądu z późniejszymi danymi źródeł antycznych oraz danymi z zakresu hydronimii (po Neurach bowiem pozostało wiele więcej hydronimów niż po późniejszych Wenetach!), poddaje go w wątpliwość, pozwalając rozciągać na zachód siedziby Neurów najdalej do linii Wisły. ${ }^{23}$

Dużo z tego, co wiemy na temat szósto- i siódmowiecznych Słowian pochodzi z relacji współczesnych im autorów piszących po grecku, a także w mniejszym stopniu po łacinie i syryjsku. Większość z nich nie zwracała

\footnotetext{
${ }^{21}$ G. LabudA, Fragmenty dziejów Stowiańszczyzny Zachodniej, t. 3, Poznań 1975, s. 71.

${ }^{22}$ Tyszkiewicz, Stowianie w historiografii (cyt. w przyp. 18), s. 167; por. H. ŁowmiAński, Początki Polski. Z dziejów Stowian w I tysiacleciu n.e., t. 1, Warszawa 1964, s. 201-203 - tu także o niewystarczającej inicjatywie penetracji gospodarczej ze strony Cesarstwa.

${ }^{23}$ Tyszkiewicz, Stowianie w historiografii (cyt. w przyp. 18), s. 168.
} 
większej uwagi na Słowian, ale tylko wspominała o nich tu i ówdzie, gdy wydawało się, że ich losy łączą się jakoś z losami imperium. Łowmiański wyraźnie zaznacza związek dwóch fal słowiańskiej ekspansji, z których pierwsza, u schyłku IV w., związana była z inwazją Hunów, a druga - z inwazją awarską, w obu przypadkach zaś ludy tureckie plądrowały ziemie Imperium, pogrążonego od jakiegoś czasu w gospodarczo-społecznym kryzysie. ${ }^{24}$

Niektóre z relacji źródłowych były spisane przez naocznego świadka, jednak większość została napisana $\mathrm{z}$ dużej perspektywy czasowej i z pewnego dystansu. Dystans ów zaś skłaniał autorów starożytnych i wczesnośredniowiecznych do posługiwania się stosownymi w ich literaturach topoi. ${ }^{25}$ Co istotne więc - główną nić narracji należy rekonstruować wybierając spośród różnych punktów widzenia i perspektyw. ${ }^{26}$ Zasygnalizowane przed chwila rozróżnienia dają wyraz wstępnie zaproponowanemu rozróżnieniu na rzeczywistość dziejową według podziału Bogusława Gedigi, ${ }^{27}$ na co w kontekście badań historiograficznych wskazał już m.in. Strzelczyk wzmiankując historię realną i wyobrażenia obcych, tworzące różne przecież narracje historiograficzne. ${ }^{28}$ Strzelczyk zastrzega jednocześnie, że badanie etnogenetyczne Słowian na gruncie historiografii nie powinno odnosić się do autorów posądzanych o najwcześniejszą datację ich tekstów względem opisywanego zjawiska (np. Neurów i Budynów Herodota z Halikarnasu z V w. p.n.e., ${ }^{29}$ Wenetów/Wenedów

${ }^{24}$ Łowmiański, Początki Polski (cyt. w przyp. 22), s. 209.

${ }^{25}$ A. Poroń, „Zagadnienie origines gentium w dworskiej historiografii bizantyjskiej. Głos w dyskusji”, [w:] S. Rosiк, P. Wiszewski (red.), Origines mundi, gentium et civitatum, Wrocław 2001, s. 91.

${ }^{26}$ Por. wstęp w: M. PleziA, Greckie i łacińskie źródta do najstarszych dziejów Stowian, Poznań - Kraków 1952, tamże wcześniejsza literatura. Dzieło to po bez mała półwieczu wciąż pozostaje klasycznym zbiorem świadectw pisarzy greckich i łacińskich dotyczących najstarszych dziejów Słowian. Ono również stanowi podstawę większości tłumaczeń tekstów omawianych w niniejszym artykule.

${ }^{27}$ B. GEDIGA, „Kultura łużycka a rzeczywistość dziejowa”, [w:] S. TABAczYŃsKI (red.), Kultury archeologiczne a rzeczywistość, Warszawa 2000, s. 91-100; por. również: A. CIEsIELSKA, „Ideologie jako narzędzie konstruowania narracji archeologicznej”, [w:] B. GEDIGA, W. PIoTROWSKI (red.), Archeologia - Kultura - Ideologia, Biskupin 2004, s. 265.

${ }^{28}$ STRZELCZYK, „Etnogeneza Słowian” (cyt. w przyp. 6), s. 20-21.

${ }^{29}$ Swoje wątpliwości wyraził w tej kwestii m.in. L. Tyszkiewicz; zob. L. TyszkiEwicz, Stowianie i Awarowie. Organizacja plemienna Stowian, Wrocław - Warszawa - Kraków - Gdańsk Łódź 2009, s. 11. 
u autorów rzymskich i Lugiów m.in. u Strabona), ale raczej do autorów, których teksty proponują kompleksowe ujęcie uniwersum słowiańskiego, tak synchronicznie, jak genetycznie. $Z$ tego też powodu Strzelczyk proponuje rozpoczynać analizy od dzieł Jordanesa oraz Prokopiusza z Cezarei. ${ }^{30}$

Na znaczenie dzieła Jordanesa oraz Prokopiusza z Cezarei wskazuje także Tyszkiewicz, rozpoznając $\mathrm{w}$ jednym i drugim moment przełomu w historiografii bizantyńskiej, z tym że na pierwszym ciążyła jeszcze antyczna terminologia chorograficzna, a drugi „stał na czele nowego pokolenia historyków bizantyńskich", dla których

Słowianie nie byli już jakimś nowym, dziwnym północnym ludem pod względem etnicznym, zamieszkałym w pobliżu granic Bizancjum. (...) Był to już stały topos etniczny w ramach nowych zadań politycznych. ${ }^{31}$

Jak zauważa Plezia, Prokopiusz z Cezarei jest być może pierwszym autorem starożytnym, którego dzieło przynosi co prawda fragmentaryczną, ale obfitą relację dotyczącą Słowian, zawartą w ks. IV rozdz. 14 De bello Gothico. ${ }^{32}$ To od niego pochodzi pierwsza pewna wiadomość o napadzie Antów na posiadłości bizantyńskie, mającym miejsce za panowania Justyna (518-527), a także wiadomości o nasileniu ataków antyjskich za Justyniana (527-565) oraz o czasowym osłabieniu tejże ekspansji po 545 r., wynikającym najprawdopodobniej z zatargów sklaweńsko-antyjskich oraz polityki Imperium zmierzającej do wciągania Słowian w służbę wojskową. ${ }^{33}$

Prokopiusz określany bywał jako głos senatorskiej opozycji względem reżimu Justyniana, o czym świadczy jego „krwawy paszkwil” na Justyniana i jego żonę Teodorę obdarzony przez potomnych tytułem Historia tajemna albo Historia sekretna. ${ }^{34}$ Zapewne Prokopiusz zwracał się do publiczności, która pamiętała jeszcze dzieła Homera, Herodota i Tukidydesa. Jego określe-

\footnotetext{
${ }^{30} \mathrm{~W}$ świetle poczynionej wyżej uwagi na temat zaangażowania interpretacji Tacytowej Germanii u J. Kolendy, należy zaznaczyć, że w podobny sposób klasyfikacja źródeł pisanych u J. Strzelczyka służy poparciu tezy autochtonicznej.

${ }^{31}$ Tyszkiewicz, Stowianie i Awarowie (cyt. w przyp. 29), s. 8.

${ }^{32}$ PleziA, Greckie i łacińskie źródta (cyt. w przyp. 26), s. 63.

${ }^{33}$ Łowmiański, Początki Polski (cyt. w przyp. 22), s. 262-264.

${ }^{34}$ Kuranc, „Sposób przedstawiania dziejów” (cyt. w przyp. 18), s. 93.
} 
nia na słowiańskie bóstwo jako „twórcę błyskawic”35 z pewnością przywodzi na myśl Sofoklesa, co nie może dziwić w świetle jego wyrafinowania. ${ }^{36}$ Pomimo jego zapewnień, że pisał relację jako naoczny świadek, jego stanowisko trudno sprawdzić, ponieważ Prokopiusz zwykle nie podawał żadnych źródeł, z których korzystał. Badacze często zgłaszają więc wiele wątpliwości co do autentyczności jego przekazu. ${ }^{37} \mathrm{Z}$ kolei zdaniem Tyszkiewicza

Prokop był nie tylko pierwszym, ale i największym historykiem bizantyńskim, a nawet największym historykiem piszącym w języku greckim od czasów Polibiusza ${ }^{38}$

a probierz jego spostrzeżeń dotyczących Słowian stanowi fakt, że posiłkował się głównie relacjami Słowian w Bizancjum przebywających „w wojsku i w cywilu".

Antropologiczny ekskurs dotyczący Słowian jest jednak najdłuższym tego przykładem w całym jego dziele. Wydaje się, że autor świadomie nie rozwija tematu geograficznego położenia kraju Słowian, być może uważając, że jest to fakt jemu współczesnym dobrze znany. Dlatego poza ogólnymi wskazówkami brakuje w jego tekście szczegółowych wyznaczników geograficznych jak np. u Jordanesa. Skąpe informacje geograficzne Prokopiusza pozwalają umiejscowić słowiańskie siedziby jedynie na północ od granicznej rzeki cesarstwa, ale - co Tyszkiewicz podkreśla - stanowią potwierdzenie pełniejszej w tym zakresie relacji Jordanesa:

Słowianie mieszkali więc za Dunajem od delty rzeki aż do węzła wodnego na zachodzie, to jest do ujścia Sawy do Dunaju. ${ }^{39}$

${ }^{35}$ „Uważają bowiem, że jeden tylko bóg, twórca błyskawicy, jest panem całego świata i składają mu w ofierze woły i wszystkie inne zwierzęta ofiarne” (M. PleziA, Greckie i łacińskie źródta [cyt. w przyp. 26], s. 69).

${ }^{36}$ J. Kuranc wymienia Prokopiusza z Cezarei, a także Priskosa z Panion, Kandyda z Izaurii, Menandra Protektora, Jana z Epifanii oraz Teofylakta Simokattę, jako historiografów związanych z czynną polityką, której cele realizują żądania dworu panującego, a przynajmniej - jak w przypadku Prokopiusza - są przy elicie społecznej; KuRANC, „Sposób przedstawiania dziejów” (cyt. w przyp. 18), s. 76.

${ }^{37}$ Ibidem, s. 93.

${ }^{38}$ Tyszkiewicz, Stowianie i Awarowie (cyt. w przyp. 29), s. 10.

${ }^{39}$ Ibidem, s. 18. 
Pewnych wskazówek badacze doszukują się interpretując anegdotyczne wzmianki Prokopiusza dotyczące Sklawinów przy okazji historii Hildigisa oraz wędrówki Herulów. Szczególnie wędrówka Herulów stanowi często przywoływany w literaturze argument na rzecz tezy o autochtonizmie lub allochtonizmie Słowian w międzyrzeczu Odry i Wisły. Prokopiusz opisuje wędrówkę Herulów, którzy przemierzali kolejno ziemie Sklawinów, „pusty, niezamieszkany kraj”, terytorium Warnów, ziemie Danów, morze aż po Thule. ${ }^{40}$ Przyjmując, jak Pavol J. Šafárik, że Herulowie wywędrowali w kierunku północno-zachodnim przez Bramę Morawską (co sygnalizował później również Labuda), można wnioskować o stosunkowo wczesnym zasiedleniu przez Słowian międzyrzecza Odry i Wisły, jednak przyjmując, że wędrówka Herulów odbywała się szlakiem wschodnim, np. przez jedną z przełęczy zachodniokarpackich i dalej przez Śląsk i Małopolskę, gdzie mieliby napotkać plemiona słowiańskie, jak chciał tego Łowmiański - z międzyrzeczem Odry i Wisły można wówczas wiązać ów „pusty, niezamieszkany kraj”. ${ }^{41}$ Jak podkreśla Tyszkiewicz - relacja Prokopiusza dotycząca pustki osadniczej na północ lub północny zachód od siedzib Słowian jest jedną z istotniejszych poczynionych przezeń uwag, której nie sposób przemilczeć. ${ }^{42}$

Wzmiankowany antropologiczny ekskurs obejmuje długą listę tematów: organizację polityczną, religię, konstrukcje mieszkalne, strategie wojenne, język, wygląd fizyczny, nazwę etniczną i terytorium. Ten nacisk wskazuje jasno na zainteresowanie Prokopiusza i jego publiczności kwestią słowiańską. Z pewnością wpływ na rosnące zainteresowanie miał ogólny charakter relacji łączących Bizancjum ze Słowianami: od stosunków pokojowych po opisy najazdów i łupieżczych wypraw, poprzez chwilę względnego spokoju - sojuszu. ${ }^{43} \mathrm{Na}$ ów obfity w szczegóły opis słowiańskiego uniwersum należy spoglądać krytycznie, tzn. w zgodzie z sugestią Tyszkiewicza, że nawet najbardziej szczegółowe doniesienia na temat słowiańskiej rzeczywistości, jeśli

${ }^{40}$ Ibidem, s. 22-24.

${ }^{41}$ Łowmiański, Początki Polski (cyt. w przyp. 22), s. 303-310.

${ }^{42}$ Tyszkiewicz, Stowianie i Awarowie (cyt. w przyp. 29), s. 24.

${ }^{43}$ Okazuje się, że dzieje kontaktów bizantyńsko-słowiańskich stanowiły również jeden z głównych przedmiotów zainteresowania licznych słowianoznawców, reprezentujących różne dziedziny nauki, jak P. J. Šafárik, L. Niederle, H. Łowmiański, A. Dvornik, K. Jażdżewski (ibidem, s. 15). 
wyrażone zostają w tak obcym dla nich języku jak greka, muszą nosić ślady schematyzacji podług rzymskich kryteriów. ${ }^{44}$ Trzon swego opisu Prokopiusz stworzył opierając się zapewne na informacjach, które dostał od sklaweńskich i antowskich najemników we Włoszech, z którymi prowadził rozmowy. Jednakże jego wiedza o Słowianach, której daje wyraz już po powrocie do Konstantynopola, wydaje się oparta na jakichś źródłach archiwalnych i zasłyszanych opowieściach. $\mathrm{Z}$ całego wywodu Prokopiusza na temat charakterystyki Słowian, ze względu na cel niniejszych rozważań, należy przytoczyć, że

1) ocenił ich nader korzystnie, jako lud pozbawiony skłonności do czynienia zła i pełen „prostoty”;

2) zwrócił uwagę na prymitywność kultury Słowian: rozproszone osadnictwo (od którego wywodził etymologicznie nazwę „Sporów”), które wskazywało na żywot nomadów;

3) podkreślił jedność etniczno-językową Antów i Sklawinów;

4) potwierdził zauważoną już przez Pseudo-Cezariusza skłonność Słowian do życia $\mathrm{w}$ demokracji i wynikający $\mathrm{z}$ tego niewielki autorytet władców plemiennych. ${ }^{45}$

Istotnych różnic dopatrywano się między relacją Prokopiusza a relacją współczesnego mu Jordanesa. Pisząc swą Historię gocka, zwaną również Getica, Jordanes mógł być zaangażowany w jakąś polemikę z Prokopiuszem na temat nastawienia Imperium względem barbarzyńców, w szczególności Gotów. Przyglądając się jednak bliżej dziełu Jordanesa zauważamy, że polemika z Prokopiuszem nie odnosiła się tylko do tej jednej kwestii. Kiedy opisuje quasi-legendarne pochodzenie Słowian, Jordanes wskazuje na Wenetów, Prokopiusz zaś na Sporów (Sporoi). ${ }^{46}$ Prokopiusz zalicza Sklawenów i Antów do nomadów, Jordanes twierdzi, że zasiedlają oni bagna i lasy. Prokopiusz lokalizuje Sklawenów blisko naddunajskiej rubieży Imperium, Jordanes zaś upatruje ich siedzib bardziej na północ, w rejonie Wisły. Prokopiusz podkreśla, że Sklawenowie i Antowie nie są rządzeni przez jednego

\footnotetext{
${ }^{44}$ Tyszkiewicz, Stowianie i Awarowie (cyt. w przyp. 29), s. 32.

${ }^{45}$ Ibidem, s. 33.

${ }^{46}$ A. ŁuKASZEwicz, „Kilka uwag o Słowianach (na marginesie tekstów greckich i łacińskich)”, Światowit 1 (2005), s. 74.
} 
człowieka, ale że od dawna żyją w demokracji; Jordanes wspomina zaś o królu Antów, Bozie. Przykłady można jeszcze wyliczać. Wydaje się, że jedna relacja stanowiła odpowiedź na drugą, ale trudno dociec, który została opublikowana pierwsza. Potwierdza to również zbieżność w czasie ich świadectw. ${ }^{47} \mathrm{Z}$ pewnością jednak, w porównaniu z dziełem Prokopiusza, świadectwo Jordanesa na temat Słowian jest słabo doinformowane. Poza zlokalizowaniem ich w Scytii jedyne, co o nich Jordanes wie, to to, że wybierają bagna i lasy na osady, a wzmianka ta może mieć daleką paralelę w Tacytowym opisie leśno-górzystej krainy rządzonej przez Wenedów.

Wielce wymowny jest fakt, że obaj autorzy - Prokopiusz i Jordanes opisując domniemanych Słowian posługują się różnymi terminami ogólnymi. Jordanesowi „Weneci” z jednej strony stanowią jakąś reminescencję starożytnych przekazów, z drugiej - oddają „obcy”, być może germański, punkt widzenia. Z kolei opisujący współczesne przypadki Prokopiusz przywołuje termin Sporoi, zniekształcony jednak wskutek adaptacji obcego terminu do głosowni języka greckiego, co powoduje niemożliwość odcyfrowana jego pierwotnego znaczenia, oraz - jeszcze częściej - mówi o „Sklawinach” ${ }^{48}$

Jakie było źródło informacji Jordanesa na temat Sklawenów i Antów? To z pewnością kwestia najbardziej kontrowersyjna, jeśli chodzi o Getica. Dziewiętnastowieczni uczeni uznali, że Jordanes tylko skopiował, z niewielkimi zmianami, zaginioną Historię gocka Kasjodora. ${ }^{49}$ Inni uznają jego dzieło za $\mathrm{w}$ pełni oryginalne. $\mathrm{W}$ istocie istnieją pewne dowody na to, że Jordanes uczynił nieco więcej niżeli użył tylko dzieła Kasjodora jako bazy dla własnej pracy. Czy jednak informacje o Sklawenach wyszły właśnie od Kasjodora? W dygresji o Scytach Jordanes cytuje „źródła pisane” poświęcone Gotom, co często interpretowano jako wskazówkę tego, że Jordanes używał dzieła Kasjodora jako źródła. Coraz częściej wskazuje się jednak, że jednym z głównych źródeł dzieła Jordanesa była mapa. Jego wzmianka o Wenetach sugeruje jednak, że

\footnotetext{
${ }^{47}$ Por. Plezia, Greckie i tacińskie źródła (cyt. w przyp. 26).

${ }^{48}$ LaBUdA, Fragmenty dziejów Stowiańszczyzny (cyt. w przyp. 21), s. 38-39.

${ }^{49}$ Plezia, Greckie i tacińskie źródta (cyt. w przyp. 26), s. 56; por. R. URBAŃsKI, Tartarorum gens brutalis. Trzynastowieczne najazdy mongolskie w literaturze polskiego średniowiecza na porównawczym tle piśmiennictwa tacińskiego antyku i wieków średnich, Warszawa 2007, s. 65.
} 
tych map musiało być więcej niż jedna. ${ }^{50}$ Znamienna jest przy tej okazji pewna dwuznaczność, gdy Jordanes raz używa określenia Vistula („Wistula”, w par. 31), innym zaś razem Viscla („Wiskla”, w par. 34). Jednym ze źródeł, z jakiego mógł czerpać Jordanes przy tej okazji, był Pliniusz, który zlokalizował swych Wenedów razem ze Sarmatami, Scirami i Hirrami (Scytami i Cymbrami?) („Wisula”, par. 96). ${ }^{52}$ Mogło być to też jakieś antyczne dzieło podobne do Ptolemeuszowej Geografii. Jest jednakże równie prawdopodobne, że Jordanes inspirował się w tym miejscu Tacytem, ponieważ podobnie jak ten ostatni nieustannie identyfikował Wenetów z Estami (Aesti). ${ }^{53}$

W słynnym Jordanesowym „katalogu narodów” (rozdział 35), napisane jest, że Wenetowie zwani bywają Sklawenami i Antami, co może oznaczać, że byli (później) podzieleni na dwie podkategorie. Inaczej w rozdziale 119, gdzie Jordanes uznaje Wenetów za jedno z trzech określeń ("tria nunc nomina ediderunt”). Są więc podkategorią, a nie określeniem zbiorczym. ${ }^{54}$ Jego zamiarem było raczej umiejscowienie argumentu w realiach VI wieku niż zadziwianie czytelników daleką starożytnością zwycięstwa króla Ermanaryka nad ludem Scytów. Jordanes chce, aby jego publiczność uwierzyła, że Wenetowie to określenie będące wciąż w obiegu. ${ }^{55}$ Prokopiusz, współczesny Jordanesowi, słyszał tylko o Sklawenach i Antach. W istocie, jego czytelnicy musieli często słyszeć o atakach Sklawenów i Antów, ale prawdopodobnie nigdy nie słyszeli o Wenetach. O rozmiarach słowiańskiej agresji świadczy bowiem fakt, że echo paniki wywołanej atakami Słowian na Bałkanach dotarło aż do Hiszpanii, gdzie Jan z Biclar opisał atak Sklawenów na Ilirię i Trację. ${ }^{56}$ Jordanesowa wzmianka

\footnotetext{
${ }^{50}$ P. BARFORD, „Wiedzieć niewiadome. Jak możemy uprawiać archeologię rozprzestrzeniania się języków słowiańskich?”, [w:] P. URBAŃczYK (red.), Nie-Stowianie o początkach Stowian, Warszawa 2006, s. 105 i n.

${ }^{51}$ PleziA, Greckie i łacińskie źródła (cyt. w przyp. 26), s. 58-59.

${ }^{52}$ Ibidem, s. 33.

${ }^{53}$ W. NowaKowski, „Hic Svebiae finis - sytuacja etniczna na wschód od Tacytowej Swebii”, [w:] Kaczanowski, PArczewski (red.), Archeologia o początkach Stowian (cyt. w przyp. 6), s. 122 .

${ }^{54}$ Np. W. Hensel, Skąd przyszli Stowianie, Warszawa 1984, s. 169.

${ }^{55}$ J. Kolendo, „Wenetowie a Słowianie”, [w:] Spór o Stowian (cyt. w przyp. 13), s. 24.

${ }^{56}$ Plezia, Greckie i łacińskie źródła (cyt. w przyp. 26), s. 125. O niepokojach wywołanych stałym zagrożeniem ze strony nomadycznych plemion barbarzyńskich (w tym słowiańskich)
} 
o Wenetach łączy więc narrację historii Gotów z wydarzeniami, które mają miejsce za jego życia. Taka narracyjna strategia miała jednak swoje słabe punkty i nie była do końca przemyślana, ponieważ autor niezgrabnie nawarstwił przy tym niejasną mapę geograficzną inwazji jego czasów na etniczną konfigurację opisaną w swym „katalogu narodów”. ${ }^{57}$ Zdaniem innych autorów terminologiczny podział zaproponowany przez Jordanesa uprawdopodobnia istnienie już w VI w. - a być może jeszcze przed inwazją Gotów i Gepidów podziału na Słowian północno-zachodnich, określanych jako „Wenetowie”, wschodnich - „Antów”, oraz południowych - „Sklawinów”"

Przekaz Jordanesa bywa często wykorzystywany dla potwierdzenia ówczesnej obecności Słowian nad Bałtykiem. Argumentem przemawiającym na korzyść tej tezy ma być wzmianka o Vidivariach, sąsiadujących z Aestami (Prusami) u ujścia Wisły, których nazwa miała być zniekształconą wersją „Vinidariów”, utożsamianych z Wenetami. ${ }^{59}$ Stanowisku temu przeczy zdaniem H. Łowmiańskiego - przejrzysta germańska etymologia etnonimu „Vidivariów”. 60

Pomimo różnic w interpretacji opisanych fragmentów Geticów historycy zgodnie wyobrażali sobie Jordanesa jako dokładnego obserwatora etnicznej sytuacji za północną granicą Imperium w połowie VI w. ${ }^{61}$ Celem jego pracy, jak się ostatnio zaznacza, nie był jednak dokładny opis. Getica były najprawdopodobniej zamierzone jako replika wobec stanowiska Prokopiusza w bieżącej debacie na temat stosunku Imperium względem barbarzyńców. Aby wesprzeć swą argumentację autorytetem, Jordanes uczynił użytek z różnych starożytnych źródeł, zarówno w przypadku geograficznego kontekstu Scy-

na przełomie starożytności i średniowiecza wyczerpująco w: URBAŃski, Tartarorum gens brutalis (cyt. w przyp. 49).

${ }^{57}$ J. KolENDO, „Wenetowie w Europie środkowej i wschodniej. Lokalizacja i rzeczywistość etniczna”, Przegląd Historyczny 75 (1984), s. 54.

${ }^{58}$ LabudA, Fragmenty dziejów Stowiańszczyzny (cyt. w przyp. 21), s. 38.

${ }^{59}$ Ibidem, s. 104.

${ }^{60}$ Łowmiański, Początki Polski (cyt. w przyp. 22), s. 314-315.

${ }^{61} \mathrm{~W}$ przypadku dzieła Jordanesa z pewnością w większości są to badacze skłaniający się ku teorii autochtonicznej, por. np. uwagi K. Jażdżewskiego na temat Jordanesa (K. JAżDżEwsKI, „O trwałości i wiarygodności ustnej tradycji historycznej u ludów niepiśmiennych”, [w:] W. KoćKa (red.) Munera Archaeologica Iosepho Kostrzewski ... oblata, Poznań 1963, s. 12-13). 
tii, jak i jego plemiennego wypełnienia. ${ }^{62} \mathrm{Z}$ drugiej strony podkreśla się również, że Jordanes, wzorem Kasjodora, na którym oparł swoje dzieło, bronił przede wszystkim gockiej tradycji i był żywo zainteresowany, aby ziściła się przepowiadana przez Kasjodora era gocko-rzymskiej jedności. ${ }^{63}$

Perspektywa Jordanesa wydaje się więc zupełnie przeciwna do poglądu Prokopiusza. Zamiast widzieć w Słowianach zjawisko stosunkowo nowe i nomadyczne, objawiające się dopiero w trakcie wojen z Bizancjum, Jordanes nazywa ich Wenetami i przydaje im przez to starożytny rodowód. Nie wynika to jednak z błędnej chronologizacji, która miałaby być udziałem metody Jordanesa, a jest raczej konsekwencją specyficznego celu, jaki przyświecał mu przy pracy. Jak każdy inny chrześcijański historyk z V i VI wieku, Jordanes odczuwał głęboki szacunek wobec autorytetu źródeł, z których korzystał. Jordanesowe przywiązanie do źródeł było wynikiem jego tradycjonalizmu i kultu przeszłości, w szczególności gockiej. ${ }^{64}$ Wiedział, że korzystając z nich zaświadcza o prawdziwości swego dzieła. Dlatego w pełni wykorzystał historyczne i geograficzne wzmianki z dzieł swych prekursorów. Ten wniosek zadaje kłam powszechnemu twierdzeniu, jakoby Jordanes był bardziej rzetelnym i precyzyjnym źródłem dla historii wczesnych Słowian od Prokopiusza, ponieważ wykorzystał gocką tradycję ustną. Umiejscowienie przez Jordanesa Słowian na obszarze pomiędzy dolnym Dunajem, dolnym Dnieprem i źródłami Wisły, w przeciwieństwie do Prokopiusza szukającego Antów jeszcze dalej na wschód od Dniepru, ma stanowić odbicie dawniejszego stanu rzeczy, najprawdopodobniej z czasu istnienia państwa gockiego i huńskiego nad Morzem Czarnym. Dopiero po rozbiciu tych państw plemiona słowiańskie miały przesunąć się na wzmiankowany przez Prokopiusza wschodni brzeg Dniepru. Z podobnym zjawiskiem, zdaniem

\footnotetext{
${ }^{62}$ F. Curta, „Tworzenie Słowian”, [w:] Urbańczyk (red.), Nie-Stowianie o początkach Stowian (cyt. w przyp. 50), s. 28.

${ }^{63}$ URBAŃski, Tartarorum gens brutalis (cyt. w przyp. 49), s. 65-66.

${ }^{64} \mathrm{~W}$ tym kontekście ciekawe są rozważania A. Poronia w odniesieniu do tez J. Tyszkiewicza o jednorodnym i jednolitym obrazie wszystkich społeczności barbarzyńskich, który miałby być kultywowany w dziełach pisarzy bizantyńskich (Poroń, „Zagadnienie origines gentium" [cyt. w przyp. 25], s. 92). Jordanes, łącząc w swoim dziele wątki tradycjonalizmu gockiego i kanonów bizantyńskiej historiografii, wprzągłby w naturalny sposób dzieje Sklawenów w uniwersum historii ludów całego wczesnośredniowiecznego Barbaricum.
} 
Labudy, mamy do czynienia na granicy zachodniej terytorium Słowian, gdzie od końca III w. opustoszałe przez migrujących Germanów ziemie między Odrą i Łabą są sukcesywnie zajmowane przez napływających Słowian, a także na granicy północnej:

omawiana gens Vinidaria objęła siedziby Gepidów po ich odejściu na południe w poszukiwaniu lepszych ziem, tj. w połowie III w. n.e. ${ }^{65}$

W tym ostatnim przypadku, w ujęciu przywołanego badacza Słowianie mieliby jednak wrócić do własnych siedzib, czasowo tylko wyparci z nich przez napływające ze Skandynawii plemiona germańskie, o czym świadczy przekaz Ptolemeusza, a być może i będące dla niego oparciem bardziej starożytne świadectwa - Korneliusza Neposa, Pomponiusza Meli i Pliniusza. ${ }^{66}$ Również Łowmiański podkreśla, że

dane Jordanesa o stosunkach współczesnych pozostawiają wiele do życzenia, gdyż miał on wyraźne wyobrażenie tylko o bezpośrednich sąsiadach Bizancjum na odcinku dunajsko-czarnomorskim. ${ }^{67}$

Dzieło Agatiasza z Myriny pt. Historia rządów Justyniana, poświęcone walkom z Wandalami, Gotami, Frankami i Persami, kontynuuje niejako dzieło Prokopiusza z Cezarei i przekazuje je dalej Menandrowi Protektoro$\mathrm{wi}^{68}{ }^{6} \mathrm{w}$ sposób istotny jednak nie dorównuje swemu poprzednikowi. ${ }^{69}$ W istocie Agatiaszowi przyświecają inne cele aniżeli Prokopiuszowi, na co wskazuje porzucenie perspektywy dunajskiej, tj. milczenie w kwestii kontynuowania przez Antów najazdów na obszary Imperium po $551 \mathrm{r}$. Możliwe, że miało na to wpływ zakończenie wojny gockiej oraz skoncentrowanie sił Imperium w celu zahamowania antyjskiej ekspansji. ${ }^{70}$ Krótkie wzmianki dotyczące słowiańskich najemników w armii bizantyńskiej pojawiają się w kontekście walki Justyniana z Persami na terenie Kolchidy (dzisiejszej

\footnotetext{
${ }^{65}$ LaBUdA, Fragmenty dziejów Stowiańszczyzny (cyt. w przyp. 21), s. 106.

${ }^{66}$ Ibidem, s. 108.

${ }^{67}$ Łowmiański, Początki Polski (cyt. w przyp. 22), s. 214.

${ }^{68}$ Kuranc, „Sposób przedstawiania dziejów” (cyt. w przyp. 18), s. 95.

${ }^{69}$ Tyszkiewicz, Stowianie i Awarowie (cyt. w przyp. 29), s. 34.

${ }^{70}$ Łowmiański, Początki Polski (cyt. w przyp. 22), s. 65.
} 
Gruzji). A skoro Agatiasz uzyskał większość swych informacji o kampaniach rzymskich w Italii i na Kaukazie raczej ze źródeł pisanych (raportów wojskowych i dzienników kampanii) niż z własnego doświadczenia ${ }^{71}$, pytanie brzmi: czy ta zmiana nazwy powinna być przypisana tylko jemu, czy raczej nastąpiła już w źródłach, z których korzystał? Chociaż urodzony w Myrinie w Azji Mniejszej, Agatiasz większość życia spędził w Konstantynopolu. W literaturze wskazuje się na literackość narracji Agatiasza, która musiała wpłynąć na jej wartość historiograficzną. ${ }^{72}$

Nie znamy żadnego źródła dotyczącego Słowian z czasów panowania Justyna II i Tyberiusza II. Kolejną informację zawiera zaginiona obecnie Historia Menandra zwanego Protektorem. Menander pisał za panowania cesarza Maurycjusza, kontynuując pracę Agatiasza. Jego dzieło przetrwało we fragmentach zamieszczonych w De Legationibus oraz De Sententiis, dwóch zbiorach skompilowanych za panowania Konstantyna VII Porfirogenety w połowie X wieku. Praca nad Historiq Menandra została zlecona przez cesarza Maurycjusza, o czym sam Menander przekonuje we wstępie do swej historii, ponieważ autor - jako członek cesarskiej gwardii przybocznej - mógł cieszyć się dostępem do archiwów imperium. ${ }^{73}$ Dzieło prawdopodobnie składało się z dziesięciu ksiąg, które opisywały czas od końca Historii rząów Justyniana Agatiasza (558/559) aż do utraty Sirmium w 582 roku. ${ }^{74}$ Menander przykładał wielką, jeśli nie wyłączną, wagę do źródeł pisanych, w szczególności zaś materiałów pochodzących $\mathrm{z}$ archiwów. To, w połączeniu z brakiem innych źródeł dotyczących tego okresu, czyni jego dzieło szczególnie wartościowym w oczach historyków zajmujących się wczesnymi dziejami Słowian. ${ }^{75}$ Był tradycjonalistą i jego główne zainteresowania dotyczyły stosunków rzymskich z obcymi ludami, w szczególności Persami oraz Awarami, o których to jako

${ }^{71}$ Ibidem, s. 80.

${ }^{72}$ Ibidem, s. 81.

${ }^{73}$ Ibidem, s. 83. Inaczej niż Menander, Jan z Efezu był naocznym świadkiem paniki wywołanej przez ataki Awarów i Słowian za panowania Tyberiusza oraz Maurycego. Jego Historia kościelna składała się z trzech części, z czego tylko ostatnia przetrwała do dzisiaj w oryginale, a druga w przeróbce późniejszego autora (ibidem, s. 90; por. o trudnościach językowych: Tyszkiewicz, Stowianie i Awarowie [cyt. w przyp. 29], s. 51).

${ }^{74}$ Ibidem, s. 35.

${ }^{75}$ Plezia, Greckie i łacińskie źródła (cyt.w przyp. 26), s. 83. 
pierwszy pisał. ${ }^{76}$ Opisując zniszczenie terytoriów Antów przez Awarów, którzy mieli „splądrować i złupić ich ziemie”, był pod dużym wpływem stylu Agatiasza, po którym przejął schedę historiografii Prokopiusza. ${ }^{77}$ Fragment dotyczący konfliktu awarsko-antyjskiego o wysłaniu na dwór awarski posła Medzamira oraz knowaniu Kutrigurów, przynosi szereg cennych informacji dotyczących struktury społeczno-politycznej Antów, ${ }^{78}$ przy czym relacja ta najprawdopodobniej odnosi się do jednego z plemion antyjskich, zamieszkałego na granicy stref bizantyńskiej i antyjskiej, a dokładnie na obszarze rosyjsko-kijowskim, gdzie miałaby powstać bardziej rozwinięta struktura polityczna (Siewiera). ${ }^{79}$ Równocześnie cenne są jego wskazówki na temat współpracy sklawińsko-awarskiej przeciwko cesarstwu, być może w sojuszu z Antami, co później potwierdzi relacja zawarta w I księdze tzw. Cudów św. Demetriusza. ${ }^{80}$ Dane przytoczone przez Menandra wskazują nadto na daleko posuniętą niezależność Sklawinów w stosunku do Awarów, o czym przekonuje najpierw relacja o „sianiu fermentu” w obozie przeciwników, czego rezultatem była agresja kagana Bajana na plemiona sklawińskie w 578 r., a także szereg kolejnych konfliktów sklawińsko-awarskich. ${ }^{81}$ Dopiero klęska r. 578 zmusiła Sklawinów do płacenia Awarom trybutu, a bezpośrednie podporzadkowanie wojskowe nastąpiło za panowania Maurycjusza, przy czym współpraca wynikała raczej z potrzeb obu stron. ${ }^{82}$ Również późniejszy przekaz I księgi Cudów św. Demetriusza uprawnia do przyjęcia wniosku, że Sklawinów i Awarów łączył przede wszystkim sojusz militarny i to jedynie ograniczony do pewnej części Sklawinów wołoskich. Jak zauważa Łowmiański:

wprawdzie kagan rościł pretensje do zwierzchnictwa nad Sklawinami, ale źródła nie pozwalają stwierdzić, by te pretensje doczekały się realizacji. ${ }^{83}$

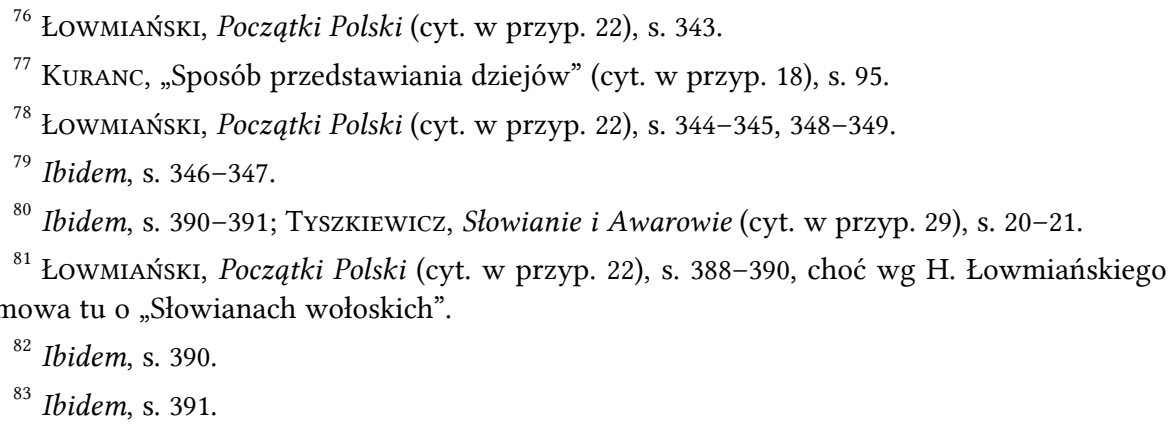


Z punktu widzenia badania najdawniejszych dziejów Słowian najbardziej istotne znaczenie przy rozpatrywaniu stosunków awarsko-słowiańskich ma fakt, że władztwo kagana awarskiego nie wykraczało poza kotlinę karpacką, czyli najprawdopodobniej nie obejmowało swym zasięgiem Słowian północnych. ${ }^{84}$

Teofylakt często porównywany jest do Grzegorza z Pizydii ze względu na utrzymywanie istotnych fragmentów swego tekstu w optymistycznym duchu lat 20. VII w., już po zwycięstwie Herakliusza, albo do Teodora Synkellosa, ze względu na styl. ${ }^{85}$ Jego Historia skupia się wyłącznie na Bałkanach i na froncie wschodnim, innymi słowy, dotyczy jedynie rzymskich zmagań z Awarami (i Słowianami) a także Persami. Stanowi jednak wyjątkowy przykład opisu ekspansji awarskiej na ziemiach polskich, której ekwiwalentem na ziemiach ruskich jest późniejsza Powieść doroczna. ${ }^{86}$ Śladem Menandra i świadectwa I księgi tzw. Cudów św. Demetriusza Teofylakt postrzega Sklawinów jako poddanych awarskich. ${ }^{87}$ Możliwe jest, że Historia Teofylakta była próbą wytłumaczenia bieżących wydarzeń w świetle polityki Maurycjusza wobec Bałkanów oraz wschodniej Europy, jako że stanowi kontynuację dzieła Menandra. ${ }^{88}$ Hipoteza ta pozwala wythumaczyć wybór Teofylakta dotyczący źródeł wzmiankujących kampanie naddunajskie przeciwko Awarom i Słowianom. Decydujące znaczenie w przekazie Teofylakta ma jego opis wyjątkowej, jak przyznaje Tyszkiewicz, kampanii Maurycjusza przeciwko Awarom, pierwszej i jedynej tego typu akcji militarnej cesarstwa skierowanej nie na północ, ale za Dunaj. ${ }^{89}$

$\mathrm{Z}$ treści przekazu Menandra oraz zamieszczonego przez Teofylakta listu kagana tureckiego do cesarza Maurycjusza da się również wywnioskować odpowiedź na pytanie o zagadkową migrację Awarów do Europy, w wyniku której nastąpił długotrwały i brzemienny w skutki okres kontaktów awarsko-

\footnotetext{
${ }^{84}$ Ibidem, s. 392.

${ }^{85}$ Odmiennie np. do świadectw Jana z Efezu, które byłyby pokłosiem pesymistycznych nastrojów panujących w Cesarstwie Bizantyńskim w „ciemnym” okresie barbarzyńskiej agresji, por. URBAŃski, Tartarorum gens brutalis (cyt. w przyp. 49), s. 23 i n.

${ }^{86}$ Łowmiański, Początki Polski (cyt. w przyp. 22), s. 370.

${ }^{87}$ Tyszkiewicz, Stowianie i Awarowie (cyt.w przyp. 29), s. 21-22.

${ }^{88}$ PleziA, Greckie i łacińskie źródła (cyt. w przyp. 26), s. 100; Tyszkiewicz, Stowianie i Awarowie (cyt. w przyp. 29), s. 52.

${ }^{89}$ Ibidem, s. 63 i n.
} 
słowiańskich. Według Łowmiańskiego dane przytoczone przez Menandra wskazują na daleko posuniętą niezależność Sklawinów w stosunku do Awarów, o czym przekonuje najpierw relacja o „sianiu fermentu” w obozie przeciwników, czego rezultatem była agresja kagana Bajana na plemiona sklawińskie w 578 r, a także szereg kolejnych konfliktów sklawińsko-awarskich. ${ }^{90}$ Dopiero w wyniku klęski w r. 578 Sklawinowie zostali zmuszeni do płacenia Awarom trybutu, a za panowania Maurycjusza rozpoczęła się - owocna zresztą dla obu stron - współpraca stricte militarna. ${ }^{91}$ Do innych wniosków dochodzi Tyszkiewicz. Do roku 582 (czyli do końca okresu będącego przedmiotem studium Menandra) Sklawinowie mieli jedynie znosić łupieżcze najazdy awarskie, ciesząc się jednak wciąż niezależnością. Dopiero po tym roku mieli ulec awarskiej potędze. ${ }^{92}$ Jednocześnie rozległy obszar zajmowany przez plemiona słowiańskie znacząco uprawdopodobnia wniosek, że zależność słowiańska od Awarów nie wyglądała tak samo na całym zajmowanym przez Słowian terytorium, co potwierdza również Łowmiański wskazując jedynie na „Słowian wołoskich” jako sprzymierzonych z Awarami. ${ }^{93}$ Zagadkowo przedstawia się również sytuacja Antów, o których Teofylakt wspomina tylko jeden raz - i jest to ostatni raz, gdy wzmianka o Antach pada w historiografii bizantyńskiej. Pisze zaś o poselstwie awarskim przysłanym do Antów, których „naród” był w tym czasie sprzymierzony z cesarstwem. Tyszkiewicz wnosi stąd o możliwości utrzymania stosunkowo szerokiej niezależności Antów wobec Awarów, a wszelkie wzmianki o słowiańsko-awarskiej współpracy ogranicza do Sklawinów. ${ }^{94}$

${ }^{90}$ Łowmiański, Początki Polski (cyt. w przyp. 22), s. 388-390.

${ }^{91}$ Ibidem, s. 390.

${ }^{92}$ Por. uwagi H. Łowmiańskiego o dalszej niezależności Słowian od Awarów: ibidem, s. 190; Tyszkiewicz, Stowianie i Awarowie (cyt. w przyp. 29), s. 54-55.

${ }^{93}$ Por. trzy modele zależności wg G. LABudA, Najstarsze państwo stowiańskie, Poznań 1949, s. 166, a także zarzuty tego autora wobec pomysłu całkowitej zależności Słowian na całym obszarze ich występowania: LABUDA, Fragmenty dziejów Stowiańszczyzny (cyt. w przyp. 21), s. 115. Skomplikowane dzieje kontaktów słowiańsko-awarskich stały się łatwą pożywką dla tendencyjnej historiografii antysłowiańskiej reprezentowanej przede wszystkim przez niemieckich (pra)historyków, rozpisujących się o „całkowitej niewoli Słowian, którzy bez jakiejkolwiek struktury organizacyjnej, pędzeni przez nomadów, jak bydło, odbyli wędrówkę na zachód (Unterwanderung)" (TyszkiEwicz, Stowianie i Awarowie [cyt. w przyp. 29], s. 62).

${ }^{94}$ Tyszkiewicz, Stowianie i Awarowie (cyt. w przyp. 29), s. 71. 
W literaturze przedmiotu wciąż nie ma zgody co do wartości świadectwa Teofylakta. Podczas gdy Plezia opisuje jego relację jako niepozbawioną historycznej perspektywy i świadczącą o obeznaniu z historiografią starożytną, ${ }^{95}$ a Tyszkiewicz dodaje możliwości, jakie przed historykiem otwierała piastowana przez Teofylakta funkcja prefekta, ${ }^{96} \mathrm{w}$ opinii innych badaczy narracja Teofylakta jest niezręcznym zlepkiem różnych świadectw, który $\mathrm{w}$ ostatnich księgach cechuje się sporą niekonsekwencją i dłużyznami. ${ }^{97}$ Zdaje się, że główny problem tkwi w tym, że będąc dalekim od bycia naocznym świadkiem rzymskich kampanii przeciwko Słowianom, Teofylakt jedynie literacko przepracował materiał ze źródeł ściśle wojskowych, licząc się z wymogami teraźniejszości.

Szczególne znaczenie dla rozważań dotyczących kwestii autochtonizmu lub allochtonizmu Słowian w międzyrzeczu Odry i Wisły w VI w. ma przytoczona przez Teofylakta niezwykła relacja o przybyciu trzech sklaweńskich posłów. Pozostawiając na boku wartość opisu posłów jako przybywających bez broni, zaopatrzonych jedynie w instrumenty muzyczne (topos „słowiańskiej sielanki" $\left.{ }^{\prime 98}\right)$, w literaturze przedmiotu zwraca się przede wszystkim uwagę na postulowane przez sklawińskich posłów ich siedziby „nad Oceanem Zachodnim”, skąd przybyli do kagana Awarów, odmawiając mu współpracy z racji odległości dzielącej ich nadmorskie posiadłości od obszarów zajmowanych przez koczowniczych Awarów. W obliczu wzburzenia awarskiego kagana sklaweńscy posłowie musieli uciekać na dwór cesarski, gdzie ich historię opisał Teofylakt, być może korzystając nawet $\mathrm{z}$ ich zeznań

\footnotetext{
${ }^{95}$ Plezia, Greckie i tacińskie źródła (cyt. w przyp. 26), s. 100.

${ }^{96}$ Tyszkiewicz, Stowianie i Awarowie (cyt. w przyp. 29), s. 52.

${ }^{97}$ P. BARFord, The Early Slavs, Ithaca, NY 2001, s. 154.

${ }^{98}$ Zdaniem G. Labudy „bezbronność” była najlepszą bronią Słowian zarówno na dworze awarskim, jak i bizantyńskim (LABUdA, Fragmenty dziejów Stowiańszczyzny [cyt. w przyp. 21], s. 117-118). Odmiennie na topos „słowiańskiej sielanki” spogląda H. Łowmiański, który kwestionuje istnienie zasadniczych różnic między modelem kolonizacji dokonywanej przez plemiona wschodniogermańskie, a tym dokonywanym przez plemiona słowiańskie. Zdaniem tegoż historyka nieznaczne różnice w charakterze kolonizacji odbijały różnice w strukturze społecznej, $\mathrm{tj}$. odmienne usytuowanie wojowników na drabinie społecznej oraz w składzie głównego trzonu społeczeństwa (Łowmiański, Początki Polski [cyt. w przyp. 22], s. 210-212; na temat przemyślanego zachowania posłów sklaweńskich: ibidem, s. 315).
} 
zachowanych $\mathrm{w}$ cesarskiej kancelarii. ${ }^{99}$ Labuda początkowo identyfikował wzmiankowaną przez posłów siedzibę z Pomorzem Zachodnim, ${ }^{100}$ jakkolwiek inni badacze odrzucają możliwość jednoznacznej identyfikacji z konkretnym obszarem. Ostatecznie Labuda także uznał, że jakakolwiek bliższa identyfikacja siedzib posłów sklaweńskich byłaby hiperhermeneuzą ${ }^{101}$ Mimo wszystko na poły legendarna relacja Teofylakta o posłach słowiańskich w stopniu o wiele większym niż kwestionowana słowiańskość Vidivarów Jordanesa osiadłych u ujścia Wisły czy wieloznaczność opisu wędrówki Herulów u Prokopiusza pozwala uznać przekaz Jordanesa

za pierwsze źródłowe potwierdzenie dotarcia Słowian w ich wędrówce na zachód i na północ od brzegów Bałtyku lub, co o wiele mniej prawdopodobne, Morza Północnego. ${ }^{102}$

Podobnego zdania jest Labuda:

poza relacją Teofylakta Simokatty nie da się odnaleźć żadnego przekazu, który by z równą dobitnością poświadczał obecność Słowian nad Bałtykiem w wieku VI n.e. ${ }^{103}$

a także Łowmiański:

ta informacja zgadza się zarówno z położeniem Wenetów w pierwszych wiekach n.e., jak z położeniem Słowian bałtyckich w wiekach średnich. Wiadomość Teofylakta stanowi ogniwo pośrednie pomiędzy odległymi okresami i poświadcza fakt ciągłości osadniczej Słowian nad Odrą i Wisłą. Nie jest natomiast jasne, czy przekroczyli oni Odrę i jak daleko posunęli się brzegiem Bałtyku w kierunku zachodnim. Rozległe pustkowia dzielące Słowian od Germanów w r. 512 nie przemawiają za tym, by dotarli oni w tym czasie nad Zatokę Wenecką. ${ }^{104}$

${ }^{99}$ Ibidem, s. 315.

${ }^{100}$ G. LabudA, Najstarsze państwo (cyt. w przyp. 93), s. 166.

${ }^{101}$ LabudA, Fragmenty dziejów Stowiańszczyzny (cyt. w przyp. 21), s. 117.

${ }^{102}$ Tyszkiewicz, Stowianie i Awarowie (cyt. w przyp. 29), s. 60.

${ }^{103}$ LabudA, Fragmenty dziejów Stowiańszczyzny (cyt. w przyp. 21), s. 122.

${ }^{104}$ Łowmiański, Początki Polski (cyt. w przyp. 22), s. 316. 
Według ostatniego z wymienionych historyków relacja Teofylakta ujawnia również jednolitość etniczną Słowian nadbałtyckich, która stanowiłaby kontrargument przeciwko domysłom niektórych badaczy o istnieniu wśród tychże Słowian warstwy panującej obcego - w domyśle: germańskiego lub skandynawskiego - pochodzenia. Szeroko rozpoznana obecność obcych elementów kulturowych oznaczałaby zatem raczej infiltrację tegoż środowiska bądź poprzez stosunki handlowe bądź w drodze pokojowej. ${ }^{105}$

W kontekście dokonywanych ostatnio badań nad strukturami władzy we wczesnośredniowiecznych społeczeństwach m.in. słowiańskich (Urbańczyk) cenne są rekonstrukcje organizacji politycznej Sklawinów dokonywane na podstawie konfrontacji przekazów Menandra oraz Teofylakta, a także drugiej serii Cudów św. Demetriusza. Na podstawie tej konfrontacji Łowmiański dochodzi do wniosku, że „organizacja ośrodków władzy nie wykazuje widocznych różnic między trzema odłamami Słowiańszczyzny”, a wzmiankowane wcześniej przez Prokopiusza ludowładztwo nie oznacza zupełnej jednolitości wewnętrznej społeczeństwa. ${ }^{106}$

Łowmiański rekonstruując wielką migrację Słowian w kierunkach zachodnim oraz południowym powołuje się również na innego rodzaju argument, będący później podstawą wnioskowania m.in. Kazimierza Godłowskiego. Za negatyw słowiańskiej ekspansji Łowmiański uznaje proces wycofywania się plemion germańskich $\mathrm{z}$ ich siedzib na skutek zmiany sytuacji w środkowoeuropejskim Barbaricum wywołany przez ataki gocko-alańskohuńskie. ${ }^{107}$ Na podstawie źródeł pisanych u schyłku IV w. dookoła granic obszaru polskiego miały zamieszkiwać plemiona germańskich Burgundów, Rugiów, Markomanów, Kwadów, Wandalów oraz Gepidów.

Jako niewiarygodny określony zostaje przez Labudę m.in. przekaz Geografa z Rawenny, będący opisem grodów i plemion na północ od Dunaju, czerpiący najprawdopodobniej wiadomości od Słowian czeskich. ${ }^{108}$ Autor tego przekazu patrzył na ludy nadbałtyckie oraz środkowoeuropejskie bądź z perspektywy rzymskiej („południowo-zachodniej”), bądź greckiej („połu-

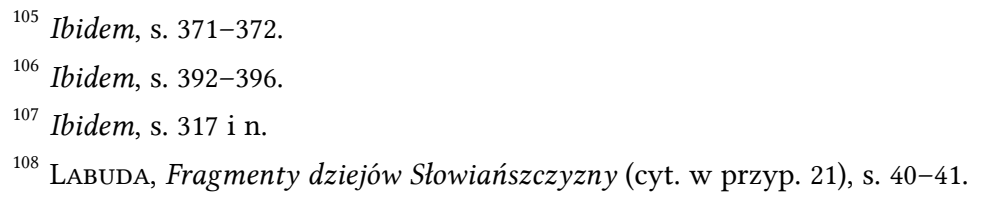


dniowo-wschodniej”), upatrując ich prakolebki w kraju zwanym „Zeriuani”. Przyczynkowy charakter względem dzieła Teofylakta mają tzw. Cuda św. Demetriusza spisane w dwóch częściach, z których autorstwo pierwszej przypisuje się arcybiskupowi Tessalonik Janowi. Po pierwsze znajdujemy tu potwierdzenie sklawińskiej zależności od Awarów, po drugie - uderza ponowny brak wzmianki o Antach. ${ }^{109}$

Z kolei Strategikon (Taktika strategika), którego autorstwo przypisuje się samemu cesarzowi Maurycjuszowi, zawiera kolejny po dziele Prokopiusza z Cezarei istotny ekskurs etnograficzny dotyczący zarówno Sklawinów, jak i Antów. Ze względu na wzmianki o tych ostatnich uważa się, że Strategikon powstał najpóźniej na przełomie VI i VII w., jako podręcznik sztuki wojennej w trakcie bizantyńsko-słowiańsko-awarskich potyczek. ${ }^{110} \mathrm{~W}$ porównaniu z etnograficznym opisem Prokopiusza wskazuje się, iż autor Strategikonu:

1) nawiązuje do uznania jedności Słowian (a także dwupodziału, a nie trójpodziału!);

2) podkreśla zamiłowanie Słowian do wolności, prowadzące nieraz do anarchii na polu bitwy;

3) po raz pierwszy wzmiankuje typową słowiańską gościnność, a także inne pozytywne przymioty: wierność i cnotliwość słowiańskich żon (decydujących się na samobójstwo po śmierci męża - Ibn Jakub), a także wyjątkowo humanitarne traktowanie jeńców wojennych;

4) potwierdza wzmiankowaną przez wcześniejsze źródła poliarchię słowiańską, która umożliwiła cesarstwu politykę divide et impera (jednocześnie potwierdza małoplemienną strukturę organizacyjną Słowian);

5) gani Słowian za typowe dla nich zrywanie umów oraz układów politycznych (casus współpracy sklawińsko-awarskiej);

6) opisując osadnictwo słowiańskie, dwukrotnie wymienia siedziby naddunajskie „wśród bagien i szuwarów”, rozścielone „gęstym pasmem” (w czym przeczy wcześniejszej relacji Prokopiusza o rozrzedzonym osadnictwie), co uprawdopodobniają inne relacje, z których można wnosić o liczbie Słowian w tym czasie; ${ }^{111}$

${ }^{109}$ Ibidem, s. 74-75.

${ }^{110}$ Ibidem, s. 75-76.

${ }^{111}$ Ibidem, s. 79. 
7) podaje wiele informacji na tematy militarne, po części potwierdzających, po części rozszerzających wcześniejsze wzmianki.

Dzięki tym wszystkim informacjom etnograficznym Strategikon, mimo że nie opisuje historii politycznej Słowian, uważa się za jedno z najważniejszych źródeł do poznania ich dziejów. Pewną wagę ma zarzut niektórych badaczy, że tego typu etnograficzne wyliczenia mają tendencję do powtarzania i utrwalania panujących obiegowych opinii - w tym wypadku Bizantyńczyków na temat Słowian.

Z wielu względów na osobne potraktowanie zasługuje Kronika Wielkanocna, której cel napisania autor podporządkował religijnej (eschatologicznej) wizji z kulminacją w momencie ocalenia Konstantynopola w 626 r., interpretowanej jako zasługa Opatrzności Bożej. ${ }^{112}$ Rekonstrukcja znaczenia tego tekstu dla wczesnej historii Słowian musi uwzględnić jednak (również?) osobisty charakter relacji autora, który był naocznym świadkiem oblężenia Konstantynopola i z tejże właśnie perspektywy ją później opisuje. Dokonany przez niego pierwszy opis walczących Słowian (sprzymierzonych z Awarami), powiela w kilku momentach dotychczasowe topoi (np. liche uzbrojenie Słowian - występowali w walce „nago”), ${ }^{113}$ jednak znaczący jest z powodu wzmiankowanego przez autora kroniki „alternatywnego” zakończenia oblężenia, zasłyszanego od kilku informatorów. Zgodnie z tym przekazem Słowianie mieli wszcząc pod Konstantynopolem bunt wobec Awarów i opuścić ich na polu bitwy, co wiązane być może, zdaniem Tyszkiewicza, z powstaniem w tym czasie państwa Samona. ${ }^{114} \mathrm{O}$ mniejszym znaczeniu bitwy z 626 r. przekonują Labuda i Łowmiański. ${ }^{115}$

Ostatnim dokumentem współczesnego historyka, który żył w czasach wczesnych Słowian, jest II księga tzw. Cudów św. Demetriusza. Żadne z kolejnych źródeł dotyczących historii Słowian nie jest oparte na autopsji i wszyst-

\footnotetext{
${ }^{112}$ Np. wybitne dychotomizowanie według cech pozytywnych i negatywnych Awarów i Bizantyńczyków: ibidem, s. 82-84. Wątki Kroniki Wielkanocnej powtarza później Nicefor w Breviarum Nicephori, nie dodając jednak zbyt wielu istotnych informacji (TyszKIEwICZ, Stowianie i Awarowie [cyt. w przyp. 29], s. 89).

${ }^{113}$ LABUdA, Fragmenty dziejów Stowiańszczyzny (cyt. w przyp. 21), s. 85.

${ }^{114}$ Ibidem, s. 87; por. przekaz Fredegara.

${ }^{115}$ Labuda, Najstarsze państwo (cyt. w przyp. 93), s. 191; Łowmiański, Początki Polski (cyt. w przyp. 22), s. 36.
} 
kie można uznać za „opowieści”, oparte w całości na starszych źródłach pisanych. Zestaw ten otwiera Zwięzty zarys historii Patriarchy Nicefora, który mógł zostać pomyślany jako kontynuacja dzieła Teofylakta Simokatty. Nicefor nie posiadał jednak żadnej osobistej wiedzy o opisywanych wydarzeniach i jest mało prawdopodobne, by zdobył ją od jakiegoś żyjącego jeszcze świadka. Źródłem wykorzystanym przy pisaniu była najprawdopodobniej konstantynopolitańska kronika, o czym świadczy fakt, że autor, obracając się wśród przedstawicieli najwyższych sfer państwowych, miał dostęp do cesarskiego archiwum. Ostatecznie kronikarze, z których dzieł Nicefor korzystał przy pisaniu swej historii, mogli mieć dostęp do naocznych świadków. W tonie podobnym do Menandra Nicefor opowiada o Słowianach oblegających stolicę cesarstwa wschodniego jako sprzymierzeńcach (poddanych?) Awarów. ${ }^{116}$

Analizując wszystkie przekazy dotyczące stosunków słowiańsko-awarsko-bizantyńskich można pokusić się o próbę periodyzacji słowiańskiej migracji w kierunku południowym. Łowmiański zaznacza, że już po pojawieniu się w Europie Awarów (558 r.) Słowianie infiltrowali rubieże Cesarstwa, jednakże zwycięstwo w wojnie gockiej i wzmocnienie słowiańskiej granicy z jednej strony, a z drugiej awarska działalność na zapleczu słowiańskiego terytorium, zadecydowały o zahamowaniu procesu. Wzmożenie naporu Słowian nastąpiło za panowania cesarza Tyberiusza (578-582), a o jego sile świadczy fakt, że nie przeszkodziły mu knowania rzymskiego cesarza, by wywołać konflikt awarsko-słowiański lub też sklaweńsko-antyjski, a nawet zawarty w 584 r. pokój bizantyńsko-awarski. ${ }^{117}$ Dopiero zakończenie wojny z Persją oraz ponowne wzmocnienie słowiańskiej flanki powstrzymało ekspansję sąsiadów z północy. ${ }^{118}$ Zmiana sytuacji nastąpiła ponownie w $602 \mathrm{r}$., częściowo za sprawą rozprzężenia siły politycznej Bizancjum za panowania Fokasa oraz ponownego wybuchu wojny z Persami, i od tej pory Łowmiański mówi już o właściwej slawizacji Półwyspu Bałkańskiego, o której nie posiadamy jednak miarodajnych źródeł pianych w rodzaju przekazów Teofylakta czy Jana z Efezu, z wyjątkiem II serii Cudów św. Demetriusza. ${ }^{119}$

\footnotetext{
${ }^{116}$ PleziA, Greckie i łacińskie źródta (cyt. w przyp. 26), s. 161-164.

${ }^{117}$ Łowmiański, Początki Polski (cyt. w przyp. 22), s. 396-398.

118 Ibidem, s. 396-398.

119 Ibidem, s. 401-406.
} 
Z czasem oprócz źródeł bizantyńskich pojawiają się również źródła łacińskie, zachodnioeuropejskie do dziejów Słowian. Najwcześniejsze oraz najbardziej liczne wzmianki w tym zakresie pochodzą z Italii, co z jednej strony wynika z jej partycypacji w strukturze cesarstwa rzymskiego, z drugiej - z nieustannego zagrożenia od strony Bałkanów. ${ }^{120}$ Palmę pierwszeństwa mają w tym zakresie dwa listy papieża Grzegorza Wielkiego, których autor ogranicza się jednak do wyrażenia zadowolenia z obrony cesarstwa i Kościoła przed bliżej nieskonkretyzowanym przez niego zagrożeniem słowiańskim, jakim były napady na Salonę i Istrię. ${ }^{121}$

O zachodniej ekspansji Słowian wzdłuż linii Dunaju, niezależnie od toczących się równolegle walk słowiańsko-awarsko-bizantyńskich, wspomina również Paweł Diakon, autor Historii Longobardów. Historyczne tło stanowi podjęcie przez Awarów ekspansji w kierunku państwa frankońskiego poprowadzonej drogą na północ przez przełęcz karpacką oraz ziemie polskie. ${ }^{122}$ Zdaniem Tyszkiewicza wartość tego źródła pochodzącego z końca VIII w. bierze się z oparcia na wiarygodnym, bo bezpośrednim przekazie, jakim była Kronika Sekundusa Tridentinusa, a w mniejszym wymiarze Origo gentis Longobardordum. ${ }^{123}$ Wespół z dziełem Grzegorza z Tours, relacja Pawła Diakona opisuje zmieniające się stosunki słowiańsko-awarskie. $\mathrm{W}$ trakcie pierwszej wyprawy awarskiej przeciwko Merowingom, której decydująca bitwa odbyła się nad Łabą w 562 r., klęska Awarów spowodowana była najprawdopodobniej uprzedzeniem przez Słowian Franków o planowanym ataku. Przypuszczalnie Słowianie lechiccy stanowili $\mathrm{w}$ owym czasie sprzymierzeńca Merowingów w ich polityce poskramiania plemion germańskich. ${ }^{124}$ Dopiero w wyniku drugiej wyprawy awarskiej, zakończonej tym razem sukcesem kagana i obłożeniem Sigiberta obowiązkiem daniny, stosunki słowiańskofrankońskie uległy rozluźnieniu, Słowianie natomiast wciągnięci zostali $\mathrm{w}$ orbitę wpływów awarskich. ${ }^{125}$ Zaangażowanie Słowian po stronie awar-

\footnotetext{
${ }^{120}$ Tyszkiewicz, Stowianie i Awarowie (cyt. w przyp. 29), s. 97.

${ }^{121}$ Ibidem, s. 98.

${ }^{122}$ Łowmiański, Początki Polski (cyt. w przyp. 22), s. 375-377.

${ }^{123}$ Tyszkiewicz, Stowianie i Awarowie (cyt. w przyp. 29), s. 99.

${ }^{124}$ Łowmiański, Początki Polski (cyt. w przyp. 22), s. 380-382.

${ }^{125}$ Ibidem, s. 382-383.
} 
skiej nie powinno być jednak tłumaczone ich podbiciem lub wyraźnym uzależnieniem, czy to politycznym, czy kulturowym, z uwagi na brak wystarczających dowodów, w tym źródeł archeologicznych, dla potwierdzenia tej tezy. W przeciwieństwie do ekspansji Hunów na ziemiach polskich, której krótkotrwałość $\mathrm{w}$ połączeniu z zaangażowaniem plemion germańskich pozostawiła wyraźne ślady zorganizowania pewnych huńskich elementów politycznych, ekspansja awarska przybrała charakter stricte polityczny, wyrażający się poprzez krótkotrwały sojusz przeciwko wspólnym wrogom. ${ }^{126} \mathrm{Z}$ drugiej strony wyraźnym rezultatem ekspansji awarskiej, dla której terytorium Polski oznaczało jedynie szlak wiodący dalej na zachód, a nie wynik parcia w kierunku północnym, stał się impuls wysłany do Słowian dla podjęcia migracji w kierunku południowym. ${ }^{127}$ Słowianie, posuwając się wzdłuż Dunaju na zachód, mieli w 593 r. nad górną Drawą zostać zaatakowani przez księcia bawarskiego Tasilo, mianowanego przez króla Franków, Childeberta, i dzięki pomocy Awarów odnieśli zwycięstwo. ${ }^{128}$ Wespół z potwierdzoną ekspansją słowiańską na terytorium Longobardów do Istrii przekaz Pawła Diakona stanowi ważne uzupełnienie historii stosunków sklawińsko-awarskich spisanej przez Teofylakta. ${ }^{129}$ Dalekim echem tych konfliktów są również przekazy pochodzące z siódmowiecznej Hiszpanii: Marcina z Brakary, Jana z Biclar oraz Izydora $\mathrm{z}$ Sewilli, jednak w świetle ich oddalenia oraz szczątkowości nie stanowią zbyt cennych źródel. ${ }^{130}$

Szczególne miejsce - zważywszy na oryginalność oraz kompleksowość ujęcia - wśród źródeł zachodnioeuropejskich do historii Słowian stanowi kronika współczesnego Teofylaktowi, żyjącego w VII w. autora znanego jako Fredegar. ${ }^{131}$ Do niedawna communis opinio brzmiała, że Kronika Fredegara, jako dość chaotyczna próba opisania historii ludzkości, jest produktem pracy trzech różnych autorów, ${ }^{132} \mathrm{z}$ których ostatni był odpowiedzialny za

126 Ibidem, s. 383-387.

${ }^{127}$ Ibidem, s. 387.

128 Tyszkiewicz, Stowianie i Awarowie (cyt. w przyp. 29), s. 100.

${ }^{129}$ Ibidem, s. 101.

${ }^{130}$ Ibidem, s. 103-106.

${ }^{131}$ Ibidem, s. $106 \mathrm{i}$.

${ }^{132}$ Przegląd stanowisk: ibidem, s. 107-116. 
kwestię wendyjską. W nauce polskiej utrwalił się przede wszystkim pogląd Plezi o jednym autorze, ${ }^{133}$ utrwalony później przez Labudę. ${ }^{134}$ Wnioskując po dowodach zewnętrznych można stwierdzić, że najbardziej interesująca w kontekście niniejszych rozważań księga IV Fredegara wraz ze wzmiankami wenedzkimi musiała zostać napisana około 660 roku. ${ }^{135}$ Jako zwolennik arystokracji z Austrazji, w szczególności rodziny Pippinidów, mityczny Fredegar mógł być nawet zaangażowany w działalność kancelarii. Celem jego kroniki wydaje się być dostarczenie rozrywki czytelnikom, co sugeruje epicki styl użyty dla opisania historii o Aecjuszu, Teodoryku, Justynianie i Belizariuszu, a także forma „zdziczałej łaciny szkolnej” (określenie Plezi), używanej raczej przez niższe warstwy społeczne, jak np. użycie na określenie Słowian słowa canes. ${ }^{136}$

Kronika Fredegara stanowi przykład gatunku określanego przez mediewistów jako origo gentis (tak jak np. Getica Kasjodora - Jordanesa, Res gestae Saxonicae Widukinda z Korwei, kronika Kosmasa, kronika Galla Anonima), czyniąc swoim zasadniczym przedmiotem etnogenezę Franków, w myśl tego dzieła, pochodzących od Trojan (Trojanersage jako topos wczesnośredniowiecnzej historiografii). ${ }^{137}$ Fredegar odwołuje się do antycznej tradycji - od Pomponiusza Meli i Pliniusza Starszego do Jordanesa - określając Słowian jako Winidi, a także Sclavi. ${ }^{138}$

Skąd Fredegar wziął informację o Samonie, Wenedzkim królu? Niektórzy sugerują, że uzyskał ją z ust Sychariusza, posła króla Dagoberta do Samona. Inni badacze sądzą, że cały ten epizod jest zmyślony. ${ }^{139}$ Co istotne, według Fredegara, Słowianie długo byli poddanymi Awarów, którzy zwali ich befulci. Słowo to powiązane jest $\mathrm{z}$ fulcfree, terminem, który pojawia się w edykcie lombardzkiego króla Rothara. Oba wyrazy wywodzą się od starogermań-

\footnotetext{
${ }^{133}$ Plezia, Greckie i tacińskie źródła (cyt. w przyp. 26), s. 127.

${ }^{134}$ G. Labuda, Pierwsze państwo słowiańskie. Państwo Samona, Poznań 1949, s. 52, 296.

${ }^{135}$ Ibidem, s. 127; TyszkiEwiCz, Stowianie i Awarowie (cyt. w przyp. 29), s. 27.

${ }^{136}$ W kontekście „zależności” od państwa Franków: TrszkiEwicz, Stowianie i Awarowie (cyt. w przyp. 29), s. 38.

${ }^{137}$ Ibidem, s. 116.

${ }^{138}$ Ibidem, s. 131.

${ }^{139}$ PlezIA, Greckie i łacińskie źródta (cyt. w przyp. 26), s. 127.
} 
skiego felhan, falh, fulgum (stąd średnioniemieckie bevelhen), co oznacza „powierzyć się w ochronę”, z drugiej jednak strony wywodzone być może od słowiańskiego byvolicy ozaczającego wołopasa. Słusznie zauważa Tyszkiewicz, że ta językoznawcza kontaminacja umożliwia dwojaką interpretację, przy czym żadna $\mathrm{z}$ nich nie musi być fałszywa. ${ }^{140}$ Dla Fredegara więc „Wendowie” było określeniem specjalnych militarnych jednostek w obrębie armii Awarów. Pojęcie befulci i jego użycie sugeruje jednakże również, że Fredegar zreinterpretował „narodowy”, prawdopodobnie wenedzki, pogląd. ${ }^{141} \mathrm{~W}$ ten sposób jego narracja ustosunkowuje się do problemu sygnalizowanego już przez Menandra. ${ }^{142}$

Kronika Fredegara rzuca również pewne światło na genezę buntu słowiańskiego przeciw Awarom. W świetle rozważań Tyszkiewicza do przesilenia społecznego mogło dojść po nałożeniu przez Awarów na ludność im poddaną tzw. hiberny. ${ }^{143} \mathrm{Z}$ drugiej strony w źródle pojawia się wzmianka, odwołująca się do funkcjonującego toposu o niższości militarnej Słowian, zgodnie z którą bunt mieli rozpocząć „mieszańcy”, będący synami Awarów zrodzonymi z gwałconych $\mathrm{w}$ trakcie hibern słowiańskich kobiet. ${ }^{144}$

Spośród wszystkich dotychczasowych przekazów Kronika Fredegara przynosi pierwsze i najpewniejsze wiadomości dotyczące wędrówek Słowian, stanowiąc, mimo wielu braków, pierwsze w pełni wiarygodne potwierdzenie obecności Słowian nad Oceanem Północnym, identyfikowanym z Morzem Bałtyckim u schyłku VI w. Dokładność informacji Fredegara umożliwia nawet rekonstrukcję słowiańskiej wędrówki w kierunku zachod$\operatorname{nim}^{145}$

\footnotetext{
${ }^{140}$ Tyszkiewicz, Stowianie i Awarowie (cyt. w przyp. 29), s. 125-128.

${ }^{141}$ Badacze różnią się co do interpretacji pochodzenia i znaczenia słowa befulci; zob. LABUDA, Najstarsze państwo (cyt. w przyp. 93), s. 324 i n.; Plezia, Greckie i tacińskie źródła (cyt. w przyp. 26), s. 129; ostatnio Tyszkiewicz, Stowianie i Awarowie (cyt. w przyp. 29), s. 27-29.

${ }^{142}$ Kwestia interpretacji słowa befulci stanowi decydujące znaczenie dla ustalenia relacji łączących Słowian z Awarami: ibidem, s. 163.

${ }^{143}$ Ibidem, s. $129-131$.

${ }^{144}$ Ibidem, s. 133.

${ }^{145}$ Lowmiański, Początki Polski (cyt. w przyp. 22), s. 332-334; Tyszkiewicz, Stowianie i Awarowie (cyt. w przyp. 29), s. 158-159.
} 
Nietrudno zauważyć różnice między przekazami antycznych pisarzy a średniowiecznymi tradycjami własnymi. Źródła własne, słowiańskie, interpretują Słowiańszczyznę w swoiście partykularnej perspektywie, różnie kładąc nacisk na jedność czy wspólnotę słowiańską. I tak, o ile nie znajdziemy o niej nawet wzmianki $\mathrm{w}$ dziele czeskiego Kosmasa $\mathrm{z}$ Pragi, a u Galla Anonima jedynie informację o organicznym związku Polski ze Słowiańszczyzną, to w Powieści lat minionych Nestora znajduje się jasna aluzja do biblijnego pochodzenia Słowian oraz pierwotnej ich jedności. ${ }^{146}$

Po mnogich zaś latach siedli byli Słowianie nad Dunajem, gdzie teraz ziemia węgierska i bułgarska. I od tych Słowian rozeszli się po ziemi i przezwali się imionami swoimi, gdzie siedli na którym miejscu. ${ }^{14}$

Na uwagę zasługuje również fakt, iż jedyną próbę budowy imperium słowiańskiego, zrzeszającego narody mówiące po słowiańsku, stanowiła ekspansywna polityka Bolesława Chrobrego w kierunku Czech, Moraw, Rusi i Miśni, inspirowana niemiecką, ottońską koncepcją Sclavinii. ${ }^{148}$ Zarówno niemiecka inspiracja, jak i fakt, że narody słowiańskie same z siebie nigdy trudu budowy takiego imperium nie podjęły, daje do myślenia w świetle wniosku o „stworzeniu Słowian” przez obcych (o czym niżej). Jednoznacznie wypowiada się A. Janaczek, wskazując jednak nadto, iż:

jedności słowiańskiej nie odnajdziemy ani w sferze gospodarczej (układ stref i powiązań gospodarczych kształtował się zupełnie inaczej), ani w sferze systemów społecznych i ustrojów prawnych. (...) Jedności tej nie było i w sferze kultury (...). Tu z jednym, lecz ważnym wyjątkiem - wspólnotę zachował język. $^{149}$

Co interesujące, zarówno Nestor, jak i Gall Anonim w swych koncepcjach, odpowiednio panońskiej i sarmackiej, posługują się modelem allochtonicznym, który wydaje się naówczas dominujący. Z tego powodu nale-

\footnotetext{
${ }^{146}$ Ibidem, s. 45-46.

${ }^{147}$ F. Sielicki, Powieść lat minionych, Kraków 1968, s. 211.

${ }^{148}$ A. Pleszczyński, „Bolesław Chrobry w Czechach. Realizacja idei Sklawinii czy zwykła ekspansja?”, [w:] H. Gmiterek, W. Iwańczuk (red.), Polacy w Czechach, Czesi w Polsce: X-XVIII wiek, Lublin 2004, s. 133-146.

${ }^{149}$ JANACZEK, „Świadomość wspólnoty słowiańskiej” (cyt. w przyp. 7), s. 22.
} 
ży zwrócić szczególną uwagę na tzw. Kronikę Dzierzwy, opartą w dużej części na Kronikce polskiej Wincentego Kadłubka (początek XIII w.), której jednak autor po raz pierwszy w historiografii polskiej nawiązuje do koncepcji wandalskiej, sprzyjającej wg B. Otwinowskiej „przeświadczeniu Polaków o ich odwiecznym pobycie na posiadanej ziemi i o starożytności ich języka" ${ }^{150}$ Ta sama autorka wskazuje jednak na rychły koniec koncepcji wandalskiej, związany z przemianami politycznymi sytuacji Polski, wchodzącej w okres jagielloński.

Sebastian Urbaniak

ORCID: 0000-0002-9334-5192

Uniwersytet Szczeciński, Instytut Filozofii sebastian.urbaniak@phd.usz.edu.pl

${ }^{150}$ B. Otwinowska, Jezyk - naród - kultura: Antecedencje i motywy renesansowej myśli o jezyku, Wrocław - Warszawa - Kraków - Gdańsk - Łódź 1974, s. 151. 
HistORIOGRAPHERS OF THE SIXTH - SEVENTH CENTURY ON THE HISTORY OF THE SLAVS: An overview of controversies in the writings of Marian Plezia, Gerard LabuDA, HENRYK ŁoWmiańsKi, AND LeCH TyszKiEwiCZ

\begin{abstract}
The problem of Slavic ethnogenesis was the subject of numerous studies and polemics. However, few authors have done systematic work to build a coherent historical narrative from individual discoveries. Among the historians who did this, one should mention Marian Plezia, Gerard Labuda, Henryk Łowmiański and Lech Tyszkiewicz. In this study, I would like to make an initial review of their concepts by looking for common threads and discrepancies. This type of work is of great importance for further research in the field of the origin of the Slavs and the search for their original homes.
\end{abstract}

Keywords: Slavs, ethnogenesis, ethnicity, history of historiography, methodology of historical studies, historical source, Marian Plezia, Gerard Labuda, Henryk Łowmiański, Lech Tyszkiewicz

Historiografowie VI i VII wieku o dziejach SŁowian: Przegląd kontrowersji W pismach Mariana Plezi, Gerarda labudy, Henryka Łowmiańskiego i Lecha TyszKIEWICZA

\begin{abstract}
Abstrakt
Problem etnogenezy słowiańskiej był przedmiotem licznych studiów i polemik. Niewielu jednak autorów dokonało systematycznej pracy, by z pojedynczych odkryć zbudować spójną narrację historyczną. Pośród historyków, którzy tego dokonali należy wymienić Mariana Plezię, Gerarda Labudę, Henryka Łowmiańskiego oraz Lecha Tyszkiewicza. W niniejszym studium chciałbym dokonać wstępnego przeglądu ich koncepcji poprzez poszukiwanie wątków wspólnych oraz rozbieżności. Praca tego typu ma niebagatelne znaczenie dla dalszego prowadzenia badań w dziedzinie pochodzenia Słowian oraz poszukiwania ich pierwotnych siedzib.
\end{abstract}

Słowa kluczowe: Słowanie, etnogeneza, etniczność, historia historiografii, metodologia badań historycznych, źródło historyczne, Marian Plezia, Gerard Labuda, Henryk Łowmiański, Lech Tyszkiewicz 